\title{
9
}

\section{Is the Thrill Gone? An Investigation of Faculty Vitality Within the Context of the Community College}

\author{
Cathic J. Peterson \\ Johnson County Community College
}

This single institutional case study investigated faculty vitality within the context of the community college by answering the following research questions: What are the characteristics of vital faculty within the community college? What effect does the environment have on faculty vitality? What do the vital faculty do to maintain their vitality? Qualitative research methods were employed to study the lives of the faculty within their naturalistic setting, thereby giving voice to the vital community college faculty.

\section{INTRODUCTION}

Community colleges have been members of the American higher education system since the early 20th century when society was changing and the need for educated workers in the nation's industries was expanding (Cohen \& Brawer, 1996; Fields, 1962, London, 1978). This transition was accompanied by the pressure for upward social mobility that necessitated citizens' access to higher education (Cohen \& Brawer, 1996; Fields, 1962; London, 1978; Lucas, 1994; Sarko, 1964). The public's demand for the opportunity to attend college was coupled with the belief in American institutions and their ability to lend authenticity, legitimacy, and credibility to an individual's pursuits and educational outcomes (Baker, 1994; Carnegie Commission on Higher Education, 1994; Cohen \& Brawer, 1987, 1996; Diener, 1986; Fields, 1962; London, 1978). 
Initially community colleges were founded on the notion of furnishing the first two years of an undergraduate education, thereby alleviating the tedious task of providing general education courses from the university's purview, hence the name junior college (Baker, 1994; Cohen \& Brawer, 1987, 1996; Deegan, 1985; Diener, 1986; Fields, 1962; Kelley \& Wilhun, 1970; London, 1978). During the past four decades, however the role of the community college and its faculty has evolved, changed, and matured, mirroring the evolution of the institutions themselves.

Researchers who examine faculty renewal at four-year colleges use the term "vitality" to investigate the manner by which faculty remain enthused and connected to their work in the higher education milieu. To date the investigation of faculty vitality has focused on vitality within the context of fouryear colleges and universities, thereby ignoring one of the fastest growing segments of the higher education system-the community college. Scholars such as Baldwin (1990), Clark and Corcoran (1985) and Schuster (1985) argue that it is of utmost importance to consider and investigate how faculty within the community college environment remain energized, enthused, and renewed given the unique culture and mission of the community college.

Currently 200,000 faculty are teaching at 1,100 community colleges throughout the United States with a national enrollment of approximately 5,500,000 students (Carter \& Ottinger, 1992; Cohen \& Brawer, 1996; U.S. Department of Education, National Center for Education Statistics, 1998). These substantial numbers illustrate the significant influence community colleges wield in the realm of higher education.

How do community college faculty remain energized, connected, and revitalized? Some community college faculty report being disconnected from their peers, are afforded limited opportunities to conduct research, work with a student population composed primarily of academically challenged students, and teach five introductory courses a semester. Many researchers argue these conditions contribute to burnout and career dissatisfaction (Baker, 1994; Clark \& Corcoran, 1985; Cohen \& Brawer, 1996; Gleazer, 1967; Grubb \& Associates, 1999; Sarko, 1964; Schuster, 1985).

There is without a doubt a paucity of research that illuminates the cultural milieu of community college faculty, who work within what some have referred to as higher education's teaching colleges (Baker, 1994; Cohen \& Brawer, 1987, 1996; Fields, 1962; Grubb \& Associates, 1999; London, 1978; Monroe, 1972; Outcalt, 2000). It is important to examine the vitality and renewal of community college faculty in lieu of the significant number of students these faculty educate, and the influential position the faculty possess, 
given that they work with students at the beginning of their college experience, a particularly vulnerable phase in many students' lives (Astin, 1984; Pascarella \& Terenzini, 1991).

The purpose of this research is to explore the concept of faculty vitality within the context of the community college. The key concepts framing this exploration are taken from Baldwin (1990) and Clark and Corcoran's (1985) case studies that examined the vitality of faculty at various liberal arts institutions and the University of Minnesota. The genesis of their studies is embedded in their concern for the health and well-being of higher education given dropping enrollments, declining budgets, and the public's increasing criticism of public education in general.

Johnson County Community College (JCCC), a Midwestern community college, was chosen as an appropriate site to research the complicated and imprecise notion of vitality, thereby answering the following research questions.

- What are the characteristics of vital faculty within the context of a community college?

- What do the vital faculty do to maintain their vitality?

- What affect (role) does the environment have on faculty vitality?

The conceptual framework guiding this study is directly connected to the research conducted by Baldwin (1990), Clark and Corcoran (1985) and Schuster (1985), who investigated faculty vitality within the liberal arts college and university settings, respectively. Their explorations revealed that faculty vitality was influenced by environmental factors found within the milieu of higher education institutions as well as the personal characteristics of the individual faculty members.

Relevant themes disclosed by the research of Baldwin (1990), Clark and Corcoran (1985), and Schuster's (1985) case studies of faculty vitality provided structure to this exploration of faculty vitality within the context of the community college. The first of the germane themes is the importance of constructive environmental factors, which include positive administrative support, a clear definition of institutional purpose, recognition of faculty accomplishments, and the appreciation of a faculty member's worth as a member of the human race. The second theme refers to the prevalence of certain personal characteristics of the faculty, such as being highly motivated to conduct research, having aspirations to be more productive than their peers, possessing 
active personality types who publish, teach, and contribute service while never feeling "stuck" in their academic profession.

Numerous scholars have explored the concept of vitality and argue that it is a primitive notion used to describe a complex phenomenon (Clark \& Corcoran, 1985), intimately associated with the social-psychological well-being of individuals within institutions of higher education (Ebben \& Maher, 1979), closely coupled to the institution's culture and administrative support as well as relationships connecting students and faculty (Centra, 1985), a complicated term difficult to summarize while being closely associated to productivity (Baldwin, 1990), and dependent upon the cultural milieu of the institution, which in turn is influenced by administrators and students (Bevan, 1985; Bogen, 1978; Schuster, 1985).

Scholars argue that the context of the community college may present different notions of faculty vitality considering that vis-à-vis community college faculty report being disconnected from their colleagues and working with an academically challenged and diverse student population while teaching an inordinately high number of classes which affords little time to conduct research. Some scholars assert that the aforementioned factors contribute to burnout, frustration, and discontentment with one's academic career (Baker, 1994; Baldwin, 1990; Clark, 1985; Clark \& Corcoran, 1985; Cohen \& Brawer, 1996; Eaton, 1994; Gleazer, 1967; Grubb \& Associates, 1999; Miller, Finley, \& Shedd Vancko, 2000; Outcalt, 2000; Sarko, 1964; Schuster, 1985). It is important to explore faculty vitality within the community college environment to reveal the pedagogical activities and classroom endeavors of the community college faculty, giving voice to the faculty who some argue fulfill American higher education's teaching college niche (Clark, 1985; Cohen \& Brawer, 1996; Eaton, 1994; Outcalt, 2000; Palmer \& Vaughan, 1992).

\section{Research Design}

The qualitative research method used to reveal the intricacies of the research site was a single institutional case study, affording access to the environmental factors which are essential to the investigation of faculty vitality. The case study also provided an avenue whereby the voices of the rescarch participants were revealed, disclosing their educational beliefs, approaches to teaching, and personal characteristics that contribute to their enthusiasm and passion for their work in the classroom. 


\section{Research Site}

Johnson County Community College was chosen as the site in which to conduct this study of faculty vitality. JCCC, a Midwestern single campus community college, founded in 1969 , is a relative latecomer to the ranks of the American community college movement. Currently JCCC is housed on 285 acres in Johnson County, Kansas, serving a credit and noncredit student population of approximately 35,000 students. The institution prides itself on providing an academic environment where "learning comes first" (Johnson County Community College, 2001-2002, p. 3).

Accredited by North Central Association of Colleges, JCCC has more than 100 articulation agreements with regional colleges and universities (Johnson County Community College, 2001). The college's annual budget is $\$ 128,042,653$ with an operating budget totaling $\$ 80,624,288$. The college's membership in the League for Innovation in the Community College is predicated upon evidence of excellence, innovation, stability, access to superior resources, and quality leadership (Johnson County Community College and the League for Innovation in the Community College, 2000).

Employing 304 full-time faculry, whose primary responsibility is to teach the more than 50 one- and two-year degree and certificate programs, JCCC affords students access to numerous employment opportunities (Johnson County Community College, 2001). Of the full-time faculty, $51.06 \%$ are women and $48.94 \%$ are men (Johnson County Community College, FY03 staff profile, internal unpublished document).

According to the vice president of instruction, approximately $30 \%$ of the full-time faculty at JCCC hold terminal degrees, whereas all (100\%) of the 304 full-time faculty have earned master's degrees.

JCCC was chosen as the institutional site most favorable for the investigation given the college's national ranking among community colleges, its membership in the prestigious League for Innovation in the Community College, and the fact that the institution affords access to over 300 full-time faculty, of which $30 \%$ hold doctorates. Finally JCCC's culture includes positive environmental conditions critical to the notion of faculty vitality. The researcher is on the staff at JCCC, making access to information easy.

\section{Selection of Vital Faculty}

Borrowing from Baldwin's (1990) research selection process, vital faculty were identified through the following research: Letrers of introduction were sent to all full-time faculty. Attached to each letter of introduction was a nomination form, which included a clearly stated definition of vitality. To be included in 
the study the faculty member had to receive at least two nominations from his or her colleagues.

The definition of vitality developed for this study reads as follows:

Vital professors are inquisitive and engaged academically. They have earned the respect of their colleagues and take pleasure in being an active member of the academic profession. It is understood that vitality will exist in many different forms. Vital professors may be academic leaders, inspirational and inspiring teachers, productive scholars, engaged advisors, but they may not participate in these roles with equal amounts of enthusiasm and proficiency. A vital professor is interested in developing collegial relationships and is truly engaged in teaching in a community college environment.

A total of 304 letters and nomination forms, which included the aforementioned definition of vitality, were distributed through the Office of the Vice President of Instruction during the spring semester 2002. After the nomination forms were returned, each faculty member's name and the frequency of nomination were recorded on a grid. A total of 94 individuals returned their nomination forms. Of those nominated, 18 faculty received at least 2 nominations and 16 agreed to participate in the study.

\section{Data Collection}

Interviews with the 16 full-time faculty who agreed to participate were scheduled during the month following the distribution of the letter requesting nominations. The interviews, which lasted approximately one and one-half to two hours were conducted in locations throughout the JCCC campus. The interviews commenced after each participant agreed to the clearly defined research parameters, which were articulated in a consent form the participants signed and dated pursuant to the University of Kansas's Human Subject Committee Lawrence Campus investigation requirements. The semi-structured interview format was employed to elucidate and clarify themes. In addition to conducting face-to-face interviews with the 16 nominees, 10 interviews were conducted with various JCCC administrators.

The researcher ensured trustworthiness of the data collection by reviewing interview notes after each conversation was completed, listening to the tape recorded interviews at least four times, and returning to the interview partners to corroborate statements, asking the interview partners to clarify statements and comments made during each interview. The data were analyzed through 
the constant comparative method recommended by Merriam (1997) to develop categories and themes by "continuous comparison of incidents, respondents' remarks" (p. 179).

\section{Limitations}

JCCC is located in one of the country's wealthiest counties; therefore, the college has rarely been faced with budgetary concerns. This fact has afforded the faculty at JCCC the opportunity to develop any number of programs and activities to support their pedagogical activities in the most positive manner. The sample of faculty interviewed was not ethnically diverse. All of the faculty who participated in this study were Caucasians affording access to no ethnically diverse faculty members. Finally, because this study was conducted in the middle to latter part of the spring semester 2002, the responses to the request for nominations may have been limited due to faculty's very busy schedules.

\section{ReSEARCh Findings}

The three research questions identified at the beginning of this chapter were used to structure a discussion of the various themes that emerged during the interviews.

\section{Who Are the Vital Faculty at JCCC?}

The seven men and nine women nominated teach the following subjects: mathematics, art history, humanities, composition, accounting, nursing, and various computer programming areas. Minority populations were not represented in the sample of faculty whose ages range from early 30 s to early $60 \mathrm{~s}$.

As illustrated in Table 9.1, nine of the participants were from the liberal arts division, two represented the computer instruction and media resources division, six taught in the science, health care and math division, and one taught in the business and technology division. Four participants began their college educations at a community college and earned their associate's degrees, 16 held both a bachelor's and master's degree, and 5 had earned terminal degrees. The average tenure teaching at JCCC was 14.5 years, the longest tenure teaching was 28 years, and the shortest tenure was 2 years.

\section{Becoming a Community College Faculty Member}

None of the 16 faculty who participated in this study indicated that they aspired to teach at a community college. After earning their undergraduate college degrees, $80 \%$ of the study participants said their career goals were to teach in the secondary schools. Anita's comments are typical, "I had no intention of 
TABLE 9.1

Faculty Nomination Demographics

\begin{tabular}{ccccc}
\hline Subject & Pseudonym & Highest Degree & Years Teaching & Department \\
\hline$\# 1$ & Evelyn & M.A. & 22 & English \\
$\# 2$ & Maxine & M.A. & 7 & English \\
$\# 3$ & Walter & Ph.D. & 20 & Humanities \\
$\# 4$ & Connie & M.A. & 26 & Mathematics \\
$\# 5$ & Sandra & M.A. & 20 & Business \\
$\# 6$ & John & M.A. & 13 & Mathematics \\
$\# 7$ & Christine & Ph.D. & 19 & Nursing \\
$\# 8$ & Maria & M.A. & 9 & Nursing \\
$\# 9$ & Rene & M.A. & 3 & English \\
$\# 10$ & Victor & Ph.D. & 19 & Humanities \\
$\# 11$ & William & M.A. & 13 & Business \\
$\# 12$ & Curtis & Ph.D. & 28 & Humanities \\
$\# 13$ & Jim & Ph.D. & 2 & Humanities \\
$\# 14$ & Corrine & M.A. & 6 & Business \\
$\# 15$ & Anita & M.A. & 9 & Humanities \\
$\# 16$ & Bob & M.A. & 9 & Science \\
\hline
\end{tabular}

*All names are pseudonyms.

teaching at a community college. I thought I was going to teach at the secondary level... " Connie said, "I fell into teaching at the community college." Eight did, in fact, say that their career as a teacher began in the secondary schools; however, their family moved or they needed part-time employment and they "fell into" the job of their dreams.

It is interesting to note that the youngest members of this study disclosed that they went to graduate school with the expressed purpose of securing 2 teaching position in higher education, whether at a university or a four-year college. It did not occur to them to seck a teaching assignment at a community college. This fact is confirmed in research conducted by Cohen and Brawer (1996) and others who have found that currently many communiry college faculty are migrating into their teaching jobs directly from graduate school rather than from the secondary education classroom. 


\section{What Are the Characteristics of Vital Faculty?}

It has been argued by Clark (1985) and others that the origins of vitality can be linked with the positive qualities individuals possess that encourage a high level of productivity. Baldwin (1990) and Schuster (1985) assert that the relationship between the individual and the institution inspire and promote vitality. So it is not surprising that the nominated faculty associated terms such as energy and enthusiasm with vitality.

Five of the faculty said vitality meant "energy and enthusiasm," "a passion and interest in the world" around them. Five faculty thought vitality meant "a sense of being alive, staying challenged, caring for self and others; being creative, active and constantly thinking about the nature of teaching and learning." Maxine likened vitality to being a "Tigger type person... they talk with their whole face-they have to try things."

The characteristics mentioned above and the personal traits of JCCC faculty are consistent with the findings of Baldwin (1990), Clark and Corcoran (1985), and Schuster (1985), who found that vitality resides in individuals who possess personal characteristics that inspire them to take their pedagogical accomplishments to a higher level. However, it is important to remember that the interaction with the institution's mission and goals enables faculty to be creative, productive, and enthused (Ebben \& Maher, 1979). The environment and cultural milieu of the institution engages the faculty, which in turn encourages them to be energetic, challenged, and creative (Baldwin, 1990; Bevan, 1985; Centra, 1985; Clark \& Corcoran, 1985; Maher, 1982; Schuster, 1985).

\section{Passion for Teaching}

Energy alone is insufficient to define vital faculty. According to Clark and Corcoran (1985) and Schuster (1985), the fundamental concepts of faculty vitality are grounded in the connection between the personal and professional goals of the faculty member and how tightly coupled faculty aspirations are aligned to institutional mission. The men and women who comprise this study are thoroughly committed to the community college's mission, and therefore find their pedagogical activities quite rewarding and stimulating. They love what they do; they feel "called" to teach within the community college environment. Their enthusiasm for teaching the community college student is all consuming.

Walter, one of the research participants, set the tone when he asserted, "I love what I am doing. Love is not too strong a word. It may not be strong cnough. It's fun. This was my calling... college teaching. ${ }^{n}$ Evelyn, who teaches 
English, said with a broad smile, "I love teaching. I have the best job on campus. I can't imagine doing anything else with my career." Bob said, "If you can see that light bulb go off in the student's eyes, it's great. Also, if you really like a subject, they pay you to learn about it and to talk about it."

\section{High Academic Standards}

Most of the faculty in this study reported setting high academic expectations for their students regardless of the fact that community college students are generally less academically prepared than their peers at universities or fouryear colleges (Cohen \& Brawer, 1996). Centra (1985) asserts that one of the fundamental elements of faculty vitality is "sound undergraduate instruction" (p. 143).

Connie, a participant in this study, stated in her book, Opportunities for Excellence: Professionalism and the Two-Year College Mathematics Faculty, that

inherent in good teaching is the establishment of high standards. As we expect and demand quality student performance, students usually respond and rise to meet our expectations of excellence. We set high performance goals for all students, regardless of race, gender, socioeconomic class or disability... We want to set ambitious goals for ourselves and for students, but we also want to make those expectations reasonable and attainable. (Neptune, 2001, p. 21)

Several quotes heard during the interviews are listed below.

- I set high standards and expect them [students] to adhere to the standards. I feel strongly about setting high standards.

- My standards are very, very high. Anybody that has ever had me in clinical will tell you that I have really, really high standards. Years later they come back to thank me.

- I have high standards and I help the students develop skills that will help them later. I give hard tests and the classroom environment is difficult, as well.

\section{Faculty Pride}

Faculty who participated in this study were gratified by the academic success of their students. Several of the faculty expressed pride in the colleges their students chose after finishing at JCCC. In fact, most of the vital faculty actively 
advised their students to look beyond the regional universities while encouraging them to consider transferring to elite Ivy League institutions.

This is an interesting topic to explore given the research conducted by Morphew, Twombly, and Wolf-Wendel (2001), who examined the formalized relationship developed between two urban community colleges and Smith College. The transfer agreements between Smith and Santa Monica and Miami-Dade "provide very bright community college students with an opportunity to attend an elite school as well as their potential to add to the richness and diversity of institutions like Smith Collegen (p. 1).

Victor indicated he was advising his brightest students to consider attending institutions such as Harvard, Yale, and Dartmouth for the very same reason, that is, "that community college students add diversity to the Ivy League institutions and benefit from an extraordinary education at an exceptional institution of higher education."

\section{How Do Vital Faculty Maintain Their Vitality?}

The JCCC faculty participate in a plethora of programs, which contribute to their vitality and enthusiasm for teaching in the community college system. They report conducting research, publishing textbooks and articles, and giving presentations at national professional conferences. Christine, a nursing instructor, says, "I have authored and written my own book on critical thinking. That was fun." Connie said, "The professor from Penn State was impressed with my work and asked me to supplement his text. I love to write." Schuster (1985) argues that purposeful production is an important component of faculty vitality, which reveals itself through the publication of textbooks and journal articles.

Learning exchange networks train faculty of the future in the pedagogical techniques of the community college. According to John, "Experienced faculty work closely with new faculty to ensure that the new faculty will get the expectations of what we think is the definition of a good teacher." John continues, "I have enjoyed working with new faculty and think the interaction has been energizing for me to think about what I am doing in the classroom."

Learning communities provide an avenue for faculty to co-teach a course with a colleague from another discipline. John's Algebra II course is combined with an English Composition 11 course. John's eyes light up when he describes the experience. "The [students] don't take any tests. They just write papers. I've taught this [math] class for nine years... to teach with someone else and have their input... It's been wonderful." 
Teacher exchange/mentor programs connect advanced graduate students from regional universities with seasoned faculty at JCCC. This program prevents burnout and encourages senior faculty to become refreshed by "teaching new courses in one's discipline" (Bishop, 1997, p. 12). Both Curtis and Jim welcomed the opportunity to work with young scholars from area universities thereby sharing their expertise and knowledge with someone considering a teaching career at a community college. According to Curtis, "the faculty find a means to remain connected to the literature of their discipline while collaborating with advanced graduate students."

Peer review is a summative and formative evaluation process of new faculty in their third year of teaching prior to awarding tenure. As a member of a peer review panel tenured faculty observe new faculty in the classroom and provide opportunities for newly hired faculty and seasoned professionals to dialogue about the process of teaching and learning. Maxine appreciates the opportunity to participate as a peer reviewer because the activity "invites peer feedback and I can improve my own teaching when I am a panel member."

Service-learning. Many of the vital faculty at JCCC said that participation in the service-learning program was a productive endeavor that contributed to their renewal and enthusiasm. According to Maria, it "provides personal and professional growth opportunities, which is a nice way to connect with the community."

Parker Palmer Formation. This initiative is clearly committed to the belief that teaching and the pedagogical activities associated with teaching and learning are important. Maria said, "This program sustains me and is a part of my everyday life both professionally and personally. It's not about teaching techniques, it's about acknowledging who you are and bringing who you are into your classroom."

National Endowment of the Humanities. Several of the faculty from the liberal arts division mentioned that the program contributes to their renewal and enthusiasm because it is a program that affords community college faculty the occasion to travel abroad while studying an academic topic of particular interest. The chair of the liberal arts division shared these thoughts: "I believe that the content is important and it opens up new material, which leads to good things for students. We're comfortable with Western Culture but we're hesitant to bring in non-Western Culture because it's not our field."

The vital faculty state that participation in the aforementioned programs affords an occasion to stretch and grow intellectually, spiritually, and academically while continually seeking new ways to teach and learn. 


\section{What Affect Does the Environment Have on Faculty Vitality?}

The following themes revealed in the literature are particularly salient issues with regard to environmental factors and their influence on faculty vitality.

- Decisive leadership and support

- A mutually acceptable mission

- Intellectually stimulating faculty development programs

- Positive interaction between students and faculty

- An atmosphere of collegiality and support for academic freedom

- Institutional recognition and rewards

- A cultural milieu that fosters open communication and a sharing of pedagogical practices (Baldwin, 1990; Bevan, 1985; Clark \& Corcoran, 1985; Grubb \& Associates, 1999; Maher, 1982; Schuster, 1985)

The 16 faculty who participated in this study stated that the support they received from the JCCC administration was crucial to their enthusiasm for teaching. They appreciated the spontaneous accolades they received from administrative staff.

The mission of the community college is unique to the landscape of higher education, and the success of its faculty is tightly coupled to the community college's mission. The faculty said they enjoyed working in the community college environment. Their enthusiasm contributes to the heart and soul of the community college and they are its most ardent supporters.

Faculty development programs. There is little doube that programs associated with the Center for Teaching and Learning and the Parker Palmer Formation group play an important role in the vitality of most faculty. The faculty in this study report that the JCCC staff development office promotes communication while fostering an interchange of pedagogical ideas limiting the isolation of faculty. Jim said, "The staff development office has been very useful. I have been given the resources to do the things I want to do."

Students in the classroom. All 16 faculty in this study stated that the students in their classrooms contribute to their vitality and enthusiasm. Repeatedly the faculty said that the students were essential to their continued enthusiasm for teaching. Connie articulated her feelings this way: "I love the interaction with the students. I love watching the lights come on in people's eyes when something clicks with them for the first time." The faculty reported that the multiplicity of the students vis-d-vis ages, academic preparation, per- 
sonal stories, and academic goals significantly enhanced their love of teaching and enthusiasm for their work as a member of the faculty.

Academic freedom. This notion is essential to the community college faculty member's vitality. Today's faculty assert that academic freedom is an influential concept crucial to their vitality. Connie shared these thoughts: "To me academic freedom is extremely important. If I felt confined that would be very wearing. It would deplete my energy. I feel energized by the freedom to design the learning activities and assessment tools in my classroom."

Grubb and Associates (1999) assert that community college faculty are quite isolated in their community college teaching endeavors, which he argues negatively influences the pedagogical activities of the classroom.

The isolation of instructors is created by the lack of any activities that might draw them together around teaching. Opportunities for learning communities and collaborative teaching are rare... Without any central forum for discussion the status of teaching is almost invisible or inaudible. (p. 285)

Rarely did the faculty at JCCC say they felt isolated. Most faculty reported that their participation in JCCC's programs eliminated isolationism while encouraging a climate of collegiality.

It is important to note that those instructors who are heavily involved in online instruction and WebCT course development did report feeling out of touch with their colleagues. This fact may warrant further investigation into the potential stress distance education/online course development and instruction may produce.

Change. Whether faculty members change textbooks, their academic course assignment, the type of students they teach, the time of day they teach, and/or introduce technology into their classroom, half of the vital faculty agree that change is an important component of an environment that fosters and encourages vitality.

Recognition and rewards. The most contentious issue this study revealed was the system of institutional recognition and rewards. The research findings support rather ambivalent attitudes, even hostility and anger, toward the formalized nomination process for awards as well as the way in which awards are disseminated. The director of staff development said, "The notion of awards in higher education has been debated extensively. Are they motivational or not? There are two schools of thought-one that awards do motivate and the other that awards are very divisive." This debate will surely continue. 


\section{Implications for Practice}

This single institutional case study of faculty vitality at JCCC has investigated the personal characteristics of the faculty as well as the environmental factors that foster and encourage their enthusiasm, renewal, and passion for teaching within the community college. This research revealed that environmental characteristics such as decisive leadership and support, a mutually acceptable mission, intellectually stimulating faculty development programs, positive interaction between students and faculty, an atmosphere of collegiality, support for academic freedom, and institutional recognition and rewards contribute to the vitality of the faculty. The personal attributes, such as an interest in the world around them, a sense of humor, a passion for teaching, high academic standards, a pride in their students and where they transfer, a competitive spirit, and a commitment to the mission of the community college also augment and enhance faculty vitality.

The outcomes of this investigation present several implications for practice. Despite budget constraints affecting most community colleges, it is imperative that community colleges continue to maintain faculty training and staff development initiatives. Change and flexibility are key components of faculty vitality; therefore, it is important to support the change of textbooks, course schedules, and/or course topics throughout a faculty member's tenure. The faculty ought to be encouraged to discuss their pedagogical endeavors with their colleagues in order to foster collegiality, which is an essential component of vitality. There is no doubt that institutional awards are a notable aspect of faculty vitality; however, the nomination process and the rationale and criteria used to determine who receives institutional rewards should be clearly defined. Academic freedom positively influences faculty vitality, and community college administrators must foster an environment where academic freedom is celebrated and encouraged.

\section{Recommendations for FutURE ResearCh}

The notion of faculty vitality within the context of the community college is an important concept requiring further research. It is recommended that future research explore the notion of burnout to discern the ways in which it might be avoided. It would be helpful to investigate the vitality of administrators, which might reveal important environmental and personal characteristics that influence administrative vitality. The 16 faculty who participated in this study were not racially diverse; given this fact, the exploration of vitality among minority faculty might provide additional insights not revealed in this study. In light of 
the recent research by Morphew, Twombly, and Wolf-Wendel (2001), which explored the formalized transfer process between two urban community colleges, an investigation of the ways in which faculty establish similar links to elite institutions of higher education would prove interesting. Finally, studying the students who comprise the vital faculty members' classrooms might be beneficial to determine whether the pedagogical activities of vital faculty members enhance learning.

The community college faculty who participated in this study love teaching and are committed to their students. Without a doubt the vitality of these individuals is closely tied to the positive environmental factors of this institution, thereby creating a synergy between the institution and the individual.

\section{REFERENCES}

Astin, A. W. (1984, July). Student involvement: A developmental theory for higher education. Journal of College Student Personnel, 25, 297-308.

Baker, G. A., III. (Ed.). (1994). A handbook on the community college in America: Its history, mission, and management. Westporr, CT: Greenwood Press.

Baldwin, R. G. (1990, March/April). Faculty vitality beyond the research university: Extending a contextual concept. Journal of Higher Education, 6I(2), 160-180.

Bevan, J. (1985). Who has the role of building incentives? In R. G. Baldwin (Ed.), New directions for higher education: No. 51. Incentives for faculty vitality (pp. 45-58). San Francisco, CA: Jossey-Bass.

Bishop, C. (1997). The community's college: A history of Johnson County Community College, 1969-1999. Pittsburg, KS: Pittcraft Printing.

Bogen, G. (1978). Performance and vitality as a function of student-faculty fit. In W. C. Kirschling (Ed.), New directions for institurional research, No. 20. Evaluating faculty performance and virality (pp. 51-67). San Francisco, CA: Jossey-Bass.

Carnegie Commission on Higher Education. (1994). The open-door colleges: Policies for community colleges. New York, NY: McGraw-Hill.

Carter, D. J., \& Ottinger, C. A. (1992). Community college faculty: A profile. Washington, DC: American Council on Education, Division of Policy Analysis and Research.

Centra, J. A. (1985). Maintaining faculty vitality through faculty development. In S. M. Clark \& D. R. Lewis (Eds.), Faculty vitality and institutional productivity: Critical perspectives for higher education (pp. 141-156). New York, NY: Teachers College Press. 
Clark, B. (1985). The academic life. Princeton, NJ: Princeton University Press.

Clark, S., \& Corcoran, M. (1985). Individual and organizational contributions to faculty vitality: An institutional case study. In S. M. Clark \& D. R. Lewis (Eds.), Faculty vitality and institutional productivity: Critical perspectives for higher education (pp. 112-138). New York, NY: Teachers College Press.

Cohen, A. M., \& Brawer, F. B. (1987). The collegiate function of community colleges: Fostering higher learning through curriculum and student transfer. San Francisco, CA: Jossey-Bass.

Cohen, A. M., \& Brawer, F. B. (1996). The American community college. San Francisco, CA: Jossey-Bass.

Deegan, W. (1985). Renewing the American community college: Priorities and strategies for effective leadership. San Francisco, CA: Jossey-Bass.

Diener, T. (1986). Growth of an American invention: A documentary history of the junior and community college movement. Westport, CT: Greenwood Press.

Eaton, J. S. (1994). Strengthening collegiate education in community colleges. San Francisco, CA: Jossey-Bass.

Ebben, J., \& Maher, T. (1979, May). Capturing institusional vitality. Paper presented at the annual forum of the Association for Institutional Research, San Diego, CA.

Fields, R. (1962). The community college movement. New York, NY: McGraw-Hill.

Gleazer, E. (1967). Preparation of junior college teachers. Educational Record, 48(2), $147-152$.

Grubb, W. N., \& Associates. (1999). Honored but invisible: An inside look at teaching in community colleges. New York, NY: Routledge.

Johnson County Community College. (2001). Fact sheet. Overland Park, KS: Author.

Johnson County Community College. (2001-2002). College catalog. Overland Park, KS: Author.

Johnson County Community College \& The League for Innovation in the Community College. (2000). Internal document. Overland Park, KS: Author.

Kelley, W., \& Wilhun, L. (1970). Teaching in the community junior college. New York, NY: Appleton-Century-Crofts.

London, H. (1978). The culture of a community college. New York, NY: Praeger.

Lucas, C. (1994). American higher education: $A$ history. New York, NY: St. Martin's Press. 
Maher, T. H. (1982, June). Institutional vitality in higher education (AAHE-ERIC Higher Education Research Currents). (ERIC Document Reproduction Service No. ED216668)

Merriam, S. B. (1997). Qualitative research and case study applications in education. San Francisco, CA: Jossey-Bass.

Miller, R. I., Finley, C., \& Shedd Vancko, C. (2000). Evaluating, improving, and judging faculy performance in two-year colleges. Westport, CT: Bergin \& Garvey.

Monroe, C. (1972). Profile of the community college: A handbook. San Francisco, CA: Jossey-Bass.

Morphew, C. C., Twombly, S. B., \& Wolf-Wendel, L. E. (2001). Two urban community colleges and an elite private liberal arts college. Community College Revieu, $29(3), 1-21$.

Neptune, C. (2001). Opportunities for excellence: Professionalism and the two-year college mathemasics faculty. Memphis, TN: American Mathematical Association of Two-Year Colleges.

Outcalt, C. (2000). Community college teaching: Toward collegiality and community. Community College Review, 28(2), 57-70.

Palmer, J. C., \& Vaughan, G. B. (1992). Fostering a climate for faculty scholarship at community colleges. Washington, DC: American Association of Community and Junior Colleges.

Pascarella, E. T., \& Terenzini, R. T. (1991). How college affects students: Findings and insights from twenty years of research. San Francisco, CA: Jossey-Bass.

Sarko, L. (1964, October). The problem of teaching in community colleges. Journal of Higher Education. 35(7), 384-386.

Schuster. J. H. (1985). Faculty vitality: Observations from the field. In R. G. Baldwin (Ed.), New directions for higher education: No. SI. Incentives for faculty vitality (pp. 21-32). San Francisco, CA: Josscy-Bass.

U.S. Department of Education, National Center for Education Statistics. (1998). Digest of education statistics. Washington, DC: Author. 